The eosinophils are quite easy to recognise, and the rest are well stained. But whether it be a peculiarity of Peking blood or a misprint in the report, I have found the solution made up as above distinctly hypotonic, and the red cells have - Been destroyed to the extent of 5 to 20 per cent. in ten minutes. To avoid this $I$ have added 0.5 gramme of sodium chloride, and get satisfactory red cell counts, but the polymorphonuclears do not stain so clearly; the stain of some becomes diffuse and others lose it altogether in 30 minutes. This laking may be a local peculiarity, for the blood of both natives and foreigners here has special features, but it is worth mentioning as there may be no other indication than a gradual reduction in the count in successive drops or an occasional "cell ghost" with the hrmoglobin in a corner. If either of these things occur, in all probability at least 10 per cent. of cells have been already destroyed. Therefore, although this method is ezceedingly handy and quick when a general idea of the blood is required, I would strongly advise that anyone who uses it should compare his results with those obtained by Toisson's fluid several times before trusting to it altogether. Even with the extra sodium chloride a little laking begins to occur after an hour or so, but for immediate use the results are quite trustworthy. I am, Sir, yours faithfully,

R. A. P. HILL.

OUtzion Medical College, Peking, China, Dec. 12th, 1911.

\section{THE PRACTICE OF MEDICINE IN BRITISH COLUMBIA.}

To the Editor of $\mathrm{TH} \mathrm{H}$ LANOET.

SIR,-Dr. G. Gibson, in The Lancet of Dec. 16th, 1911, sounds a timely note of warring as regaras the conditions nevessary for practice in British Columbia. Medical men in the old country are being tempted to buy fruit farms in the province, and it is important that they should know that their British qualifications do not entitle them to practise rout here. The examination, mereover, which they have to pass before being allowed to register is not a mere formality. Even a well-informed practitioner, unless he had done a few months' reading before the examination, might find that he had failed to satisfy the examiners. For the examination is a very comprehensive one, and rincludes many subjects which we are apt to put aside after - our student days are over.

As regards the chances of practice, they are not as good as might be imagined. It is true British Columbia is a highly prosperous country with a great future ahead of it. But it is as yet but thinly populated outside of the towns. All openings there may be are rapidly filled by medical graduates from the Canadian schools. At present there are nearly 600 names on the Wedical Register, and most of these men are in active practice. The population of the province, on the other hand, barely amounts to 400,000 (386,000 according to the last census taken in May, 1911). In the city of Vancouver, with a population of 130,000 , there are over 150 registered practitioners. The number of medical men out here is greater per capita than it is in England. It should, however, be stated that there is little or no poverty, and there are few who cannot afford to pay for medical attendance.

Dr. Gibson is, I am atraid, a little generous when he puts down $1500(£ 300)$ as what a new-comer might reasonably expect to make during his first year in Vancouver. This, moreover, only states one side of the question. Living out here, it should be mentioned, is from 75 to 100 per cent. higher than in England. It is also the custom here for medical men to have an office in the business section where rent is necessarily very high. If a man is married, and unless his wife is prepared to do all the household work, he will find the cost of servants a very heavy item. A general - servant costs from $£ 5$ to $£ 7$ per month, while it is difficult to obtain a cook (usually Chinese) at less than $£ 10$ a month. As regards special work, such as eye, ear, throat, and nose, the field is fully occupied, there being at least a dozen men engaged in these specialties.

British Columbia offers, as Dr. Gibson says, better chances, especially to the younger men, than does the old country. But, as he wisely remarks, it is a serious mistake to think that all one has to do is "to stick up one's brass plate and the patients will come pouring in." It would not be wise for anyone who intends starting in one of the coast cities (Vancouver and Victoria) to have less than a capital of $£ 300$ after arrival here. He will find that he requires that amount and more to defray preliminary expenses as well as cost of living during the time that must necessarily elapse before he will get both ends to meet from the proceeds of his practice. I am. Sir, yours faithfully,

F. L. DE V ERTEUIL. M D. Edin., M.R.C.S. Eng.,

Vancouver, Jan. 3rd, 1912. Surgeon R.N. (retired).

\section{PSYCHOTHERAPY AND GENERAL MEDICINE.}

To the Editor of THE LANCET.

SIR, - May I have space for a few remarks suggested by Dr. Branson's letter in to-day's LANCET? I have had some considerable experience of the practice of hypnotic suggestion, and hope that this will be a sufficient excuse. 1. In Dr. Branson's method he attempts to influence the patient's judgment, and in just the same way $I$ try for the same result. I do not ask the patient to "surrender his judgment." As a matter of fact, the patient will of ten refuse a suggestion which is against his reason. The hypnosis only heightens bis suggestibility and enables me to persuade him to use his own bodily powers on his own behalf. 2 . The reasoning power of the patient in a state of hypnosis is not by any means entirely suspended. I have of ten argued with the patient about the cause of a symptom, and have brought him or her to reason with excellent results. 3 The patients who are amenable to hypnotic suggestion are not "those who are hovering between the neurologist and the alienist." These are the least amenable of any. Those whom Dr. Branson uses his "rational psychotherapy" upon are the best subjects for hypnotic suggestion. In fact, what Dr. Branson calls "rational psychotherapy" is really suggestion without the aid of hypnosis, its most valuable ally. I feel sure that if Dr. Branson conld so far put aside his personal prejudice against hypnotic suggestion as to make a study of it he would very soon realise the truth of what I state and that his prejudice would rapielly disappear.

I am moved to make these remarks by the feeling that such a valuable weapon in our armoury as hypnotic suggestion should not be decried upon merely theoretical objections, which, practical experience shows, have no real basis. I am, Sir, yours faithfully,

Westcliff-on-Sea, Feb. 3rd, 1912. J AMES B. TOMBLESON.

\section{THE ADMISSION OF VENEREAL CASES TO GENERAL HOSPITALS.}

\section{To the Eaditor of THE LANCET.}

SIR, - I have read with much interest a letter with the above heading and signed "A Hospital Matron" which was inserted in THE LAANCET of Jan. 27 ch. I have also read the paper on Venereal Disease, its Present and Future, in The LANCET of Dec. 9th and 16th, 1911, written by Dr. Donglas White and Lieutenant-Colonel $c$. $H$ Melville, R.A.M.C., as well as the leading article, entitled "The Racial Importance of Venereal Diseases," in your columns of Dec. 16 sh. In this article you yourself recommend the procedure suggested by the above authors, and which is so obnoxious to "A Hospital Matron": that "in every hospital there should be accommodation for the treatment of venereal cases, both as in-patients and as out-patients."

The writer of the letter bases her objection to this measure on the disturbing effect it might have on the susceptibilities of "the ordinary well brought up girl of from 20 to 25 , the usual age at which probationers enter hospitals," and who " is ignorant of the existence of venereal disease and of the horrible consequences of contracting it," and who, therefore, "certainly should not be exposed under compulsion and in ignorance to such a vile contagion." But this seems to me hardly a valid plea to urge against admitting venereal cases into general hospitals. To begin with, they are admitted into many general hospitals every month in the year, though not into "special wards," and though not always labelled as such; and therefore apparently no exception is taken to their presence in the wards. I need only quote from an annual volume of Hospital Reports 
I have at hand that contains a list of all the medical and surgical cases admitted during the year into a large London hospital. It so happens that nearly 20 years ago that same hospital decided to close its male and female "lock ward" with 22 beds, and this was converted into a general surgical ward. I was sister of that ward afterwards for three years, and many "specific" cases came in for operation. In the reports I note gonorrhœa, 3 cases; gumma, 1 case ; tabes dorsalis, 24 cases ; syphilis, 17 cases, and there are probably others.

As regards infection, every woman who takes up nursing or midwifery knows-or ought to know - what risks she runs, while her exposure to infection only differs in degree but not in kind from that of the medical men and students who attend infective cases. The contact with certain forms of venereal disease constitutes a very serious risk to all who enter the medical or nursing professions. But women may become midwifery pupils at an age before they are admitted to some of the large general hospitals, and in district work they are exposed to far greater danger of infection from gonorrhoeal discharges and from handling infants exhibiting the external manifestations of congenital syphilis than they are likely to be exposed to in the wards of a general hospital.

A high degree of "nerve" and of moral courage is required to make an efficient type of nurse, but she also needs to carry about with her Charity's mantle. "A Hospital Matron" says very truly that "no real nursing can exist where the patient's personality is treated as nonexistent and the area of disease alone is considered." But surely this is an argument all the other way. The disease and its etiology may inspire the nurse with "horror and repulsion," but if, at the same time, it induces her to feel nothing but "disgust for its victims," I think she would be wiser in choosing some calling that makes no claim on her human sympathies. The "intolerance of youth" is not permitted to those who nurse the sick. All of us who have worked in general hospitals have had occasion to nurse "police cases." But a patient is a patient, and so long as his physical disabilities require our skilful ministrations his entire dependence on us must appeal to our nursing instincts, and we take little or no count of his moral obliquities. Incidentally, I have known this attitude to have a very humanising effect on the " sinner." And with regard to the sinner who comes to us for bodily tending I think we would do well to remember how it was once said: "Neither do I condemn thee."

I am, Sir, yours faithfully,

Hamburg, Feb. 4th, 1912. EMILIA V. KANTHACK DE Voss.

\section{BERGSON'S "CREATIVE EVOLUTION" THE NERVOUS SYSTEM IN ORGANIC EVOLUTION \\ To the Editor o THH LANCET.}

SIR,-M. Henri Bergson's new theory of organic evolntion, as brought out in his work, "L'Évolution Créatrice," a translation of which into English by Mr. Arthur Mitchell appeared a short time ago, ${ }^{1}$ is bound to have a wide influence on thinking men, since in the chaotic state of biology as regards the factors of evolution, and the complete abstention of biologists from taking an intelligent interest in Lamarckism, especially as modified by recent science, it offers to the thinking man the most plausible theory for the operations at work in organic evolution.

The leading criticism of M. Bergson as to the existing theories of evolution is that there is no indication in any of them of any factor which would make for coördination. He cites as an instance as regards natural selection one of the strongest arguments against it-viz., that it is impossible to conceive that variations occur in nature in such correlation with each other as to lead to modification dependent on the simultaneous appearance of variations in different parts of the organism-e g., in the brain and the peripheral parts correlated therewith in the eye. And one of his strongest arguments indicative of purpose in evolution is that special organs become developed on a similar plan in organisms that had diverged from the stem at a com. paratively ear]y period in evolution-e.g., the eye of molluscs and of vertebrates, and also in the case of the sexual apparatus of animals and plants, as illustratirg unity of purpose. M. Bergson is, of course, a teleologist, but it seems to me he makes his working out of the plan to depend on subsequent conditions which arise as progress is made. Back of all is the creative energy, which works upward in a definite way and always with a definite aim. Such a theory, as $\mathbb{I}$ have stated, will, no doubt, gain wide acceptance, since it postulates an initial purposeful force through which evolution has been carried on, and by which ccördination is effected. Theologians will doubtless hail it as being in harmony with, and really an explanation, if an expansion of their special creation views; and as such they will accept it as a new stronghold-in their attempt to harmonise dogmatic theology with science-especially since it seemingly is based on scientific grounds.

It will be idle for biologists to belittle it, to attempt to brush it aside by sarcasm or put it down by weight of authority; they will have to sink differences and retrace their steps in order to learn why, and how, such a theory as M. Bergson's has apparently so much truth in its favour. And in doing so they will have to go back to the teaching of Lamarck, whose theory-misunderstood in the past-in the present day, with the light of modern scientific knowledge, can be made to explain not alone the apparent trath in M. Bergson's theory, but once and for all, by demonstrating the true factors at work, lay bare the foundation on which the true process of organic evolution has been built. The absence in all theories of evolution of any factor which makes for coördination in development, as I have stated, is the characteristic feature revealed in M. Bergson's worlz. On the contrary, in Lamarckism this ccördination and correlation is made clear. How is this shown? By demonstrating that through the nervous system such a coördination is effected. It is due to the fact that the influence of the nervous system in organic evolution has hitherto been ignored by biologists that it is possible for a theory such as M. Bergson's to be advanced and apparently rendered acceptable to thinkers. Let us see how the nervous system has been developed, and let us learn how its infuence has been operative all through the progress of evolution.

The simplest organism consists of one cell. The functions of this cell are : (1) division or propagation, (2) absorption or nourishment, and (3) irritability or protection as seen in motion. When two or more cells are united to form one organism we find the same three functions; but even so low down in the scale of life as the hydra we find that certain cells are more sensitive than others and are known as newro musoular cells. "It is important," states Professsor McFarland," "to note that the purpose of the primitive nervous system seems to be to correlate external impressions with the movements directed towards the capture of food or escape from enemies." And in order to show that throngh the nervous system coördination is effected in evolution, in his chapter, "The Higher Organisms," he denotes the section on the development of the nervous system, innervation and ooördination.

For the very lowest organisms there are certain conditions in the environment to which they react. These reactions are known as tropisms, and consist for the most part of reactions to heat, motion, and chemical action in a general way. As organisms rise higher the various reactions become specialised, and the special senses, foreshadowed at an early time, are gradually developed. As, however, the various diverging lines of advance seem to respond in a similar way, it would seem that following the adjustment of living protoplasm to the environment as regards light, heat, and other physical conditions, the need is the determining factor in all cases. Professor McFarland thus writes ${ }^{3}$ : " The increasing structural complexity appears to be largely a matter of necessity"-i. e., for the satisfaction of the needs of the organism. To a physician the controlling and coördinating power of the nervous system must be clearly evident, since, as I have previously stated in your pages, he is capable of looking at the question from a standpoint of fuller knowledge than the pure biologist a standpoint gained from a study of the organism from the unicellular, the beginning, to man, the final stage. In the gradual evolution through the nervous system we have a series of gradations somewhat different from the gradatione 